\title{
Systemic Functional Linguistics Mood Analysis of the Last Address of the Holy Prophet (PBUH)
}

\author{
Mehwish Noor ${ }^{1, ~}$, Moazzam Ali ${ }^{1}$, Fakharh Muhabat ${ }^{1}$, Bahram Kazemian ${ }^{2}$ \\ ${ }^{1}$ Department of English, University of Gujrat, Punjab, Pakistan \\ ${ }^{2}$ Department of English, College of Persian Literature and Foreign Languages, Tabriz Branch, Islamic Azad University, Tabriz, Iran
}

Email addresses:

noorlinguist@gmail.com (M. Noor),m_linguist@yhoo.com(M. Ali), bahram_kazemian@yahoo.com (B. Kazemian), biyakhan38@yahoo.com (F. Muhabat)

\section{To cite this article:}

Mehwish Noor, Moazzam Ali, Fakharh Muhabat, Bahram Kazemian. Systemic Functional Linguistics Mood Analysis of the Last Address of the Holy Prophet (PBUH). International Journal of Language and Linguistics. Special Issue: Critical Discourse Analysis, Rhetoric, and Grammatical Metaphor in Political and Advertisement Discourses. Vol. 4, No. 1-1, 2016, pp. 1-9. doi: 10.11648/j.ijll.s.2016040101.11

\begin{abstract}
The study highlights the functional and semantic properties of the last address of the Holy Prophet (PBUH). The study is based upon Halliday's (1985) SFL Mood analysis. The data obtained from the last address of the Holy Prophet (PBUH) are analyzed in tables. The analysis of 56 clauses reveals that 32 are declarative, 22 are imperative; whereas, only one is interrogative clause. A brief discussion explains the functional structural meanings based on clausal Mood classification. The study of the religious text discusses interpersonal metafunction of language. It highlights the power relations of the participants. The study fills the gap of SFL based linguistic study of the religious texts. The research shall act as a torch light for young researchers for further investigation in this regard.
\end{abstract}

Keywords: SFL Mood Analysis, the Holy Prophet (PBUH), Religious Sermon, Metasunctions, Interpersonal Metaphor

\section{Introduction}

Systemic Functional Linguistics (SLF) is an effective way to analyze language on semiotic terms. The chief proponent of this approach is M. A. K. Halliday (Costetchi, 2013). It is based on non-transformation generative grammar which classifies words according to their roles within the structure (Moji, 2011). It focuses on the functions of language with reference to different contexts. It offers applied orientations to linguistics' study (Christi \& Unsworth, 2000). Choice of words is, actually, meaning in the principle of Functional grammar. This principle focuses on the functions that words perform and the meaning determined by the choice of these words (Ye, 2010).

The constituents of Mood analysis describe interpersonal metafunction of language. Mood and Residue are two main elements of the analysis. The Mood element comprises Subject and Finite sub-elements whereas Predicator, Complement and Adjunct are sub-elements of Residue. Subject (the nominal group) determines the Mood of the entire clause. (Banks, 2002). Finite expresses tense and the view of the speaker or writer (Butt et al, 2003). The part of the verb that shows event is called Predicator. Complement satisfies the argument of the clause whereas Adjunct determines the location, time, place and manner of the events. Polarity is another element of Mood Block. It can be negative or positive which expresses the aspect of the clause (White, 2000).

The sequence of Subject and Finite determines the speech roles that a clause indicates. Subject ${ }^{\wedge}$ Finite $(\wedge=$ followed by $)$, for instance, shows Declarative Mood. Finite ${ }^{\wedge}$ Subject, on the contrary, signals Interrogative Mood.

SFL provides an active approach to analyze language. The study focuses on Mood analysis (in tabulated forms) of the last Address of the Holy Prophet (PBUH). The study paves the path for future researchers to understand and analyze religious text with reference to their religious and social context.

\subsection{Theoretical Framework}

The study is based on Hallidyan (1994) SFL Mood analysis in tabular orientation. The last address of the Holy Prophet (PBUH) has been selected as a sample of the study. This sermon enjoys a universal and transcendental appeal. It needs comprehension at various linguistic levels.

This approach provides a solid theoretical underpinning to the study in order to understand the religious address and its functional meaning. 


\subsection{Research Objectives}

a) To analyze the structural aspects of the language of the religious sermon,

b) To evaluate the functional meaning of the text under study.

\section{Literature Review}

SFL is a widespread approach to analyze language with respect to its functional meaning. Young and Harrison (2004) state it as a useful orientation to carry out CDA (Critical Discourse Analysis). The researchers have the same views and find it a useful tool to analyze language with respect to its social and discourse function in social interactions.

SFL has been applied by various researchers from different dimensions. Ayoola and Olusanya (2013) study it with respect to relational aspects of political advertisements. They maintain that there is no direct relation between interpersonal meanings of language with its lexico-grammar structure. It supports the common held view about language which imparts meaning above than its structural and literal meaning. O'Halloran (2008) opines that the integration of metafunctions of language (e.g. Interpersonal) with semiotic resources to understand meaning is a great significance of Systemic Functional Linguistics (SFL). The significance of that study is the analysis of language along with its visual orientation in print media.

Post (2008) investigates stylistic and communicative aspects of two texts of the same subject matter through the application of the principles of SFL and finds it effective to analyze them. The study highlights the construction of realities through the functional properties of language. The application of SFL is very vast and productive. Banks (2002) proposes SFL as a useful model to analyze text. The author uses mini corpus for that purpose that strengthens his claim.

Moji (2011) analyses editorial's language by using SFL tools and propounds this genre of language simple and direct. Ye (2010) examines Barak Obama's Victory speech through SFL perspective and identifies different Moods of the clauses. The current study focuses on classification of the clauses of the sermon and the interpersonal meaning with respect to clausal Mood.

Kamalu and Tamunobelema (2013) study religious identities and ideologies construed in literary text. They find SFL Mood analysis useful to understand the structural based interpersonal relationships of the participants. The current research focuses on religious Address of the Holy Prophet (PBUH) with the application of the same principle to analyze its meaning. The researchers find a gap in the previous studies and select this address on the basis of its universality and uniqueness. The study offers a great deal of interest to evaluate religious text, spoken or written, in order to comprehend the surface as well as deep structure of the language.

Martinez (2001) examines objectivity in research articles with SFL application and proposes objectivity in the presentation of the text. Present study finds SFL Mood analysis more objective than the transitivity analysis done by Martinez. Mood analysis provides a framework to the study to analyze language through its structural and functional dimensions.

Eventually, some other conspicuous attempts have been made in Grammatical Metaphor, Rhetoric and Critical Discourse Analysis to sift through various texts and discourses and to identify multiple tools exploited by orators and authors in political, scientific etc. texts to make the texts persuasive, influential, and appealing and obscure as well (Behnam \& Kazemian, 2013; Kazemian et al, 2013; Kazemian \& Hashemi, 2014a, b; Kazemian, 2014).

\section{Research Methodology}

Religious preaching is a very important function of language that enjoys a particular religious and social context. The sermon has been analyzed at different levels. Clause is the highest constituent at rank scale that is further classified into SFPCA \{subject, Finite (negative/positive), Predicator, complement and Adjunct\} elements. Final classification contains the main two elements of Mood analysis: Mood block and Residue. A brief descriptive discussion, according to the clausal Mood, has been presented at the end of the paper.

\section{Data Analysis}

Translated manuscript of the address of the Holy Prophet (PBUH) in English (Bayram, 2010) has been selected as data sample. Classification of the clauses has been done according to their semantic unity due to the fact that SFL considers context and meaning essential. Data analysis in tabulated form is presented as follows:

Clause 01. O People, lend me an attentive ear.

\begin{tabular}{|c|c|c|c|c|c|}
\hline O People & & lend & & Me & an attentive ear \\
\hline Adjunct: Vocative & $\begin{array}{l}\text { Subject } \\
\text { MOOD: Imperative }\end{array}$ & Finite & $\begin{array}{l}\text { Predicator } \\
\text { RESIDUE }\end{array}$ & Complement & Complement \\
\hline
\end{tabular}

Clause 02. for I know not whether after this year

\begin{tabular}{lllll}
\hline For & I & know not & Whether & after this year \\
\hline & Subject & Finite & Predicator: negative & Adjunct: conjunctive \\
& MOOD: Declarative & RESIDUE & \\
\hline
\end{tabular}


Clause 03. I shall ever be amongst you again

\begin{tabular}{lllll}
\hline I & Shall & ever & Unhealthy & Mothers morning \\
\hline Subject & Finite: modal & Adjunct: Mood & Adjunct: Circumstantial & Complement \\
MOOD: Declarative & & RESIDUE & \\
\hline
\end{tabular}

Clause 04. Therefore, listen to what I am saying to you very carefully.

\begin{tabular}{lllll}
\hline Therefore & \multicolumn{2}{c}{ listen to } & what I am saying to you & very carefully \\
\hline Adjunct: conjunctive & Subject & Finite & Predicator & Complement \\
& MOOD: Imperative & RESIDUE & & Adjunct: Circumstantial \\
\hline
\end{tabular}

Clause 05. and take these words to those who could not be present here today.

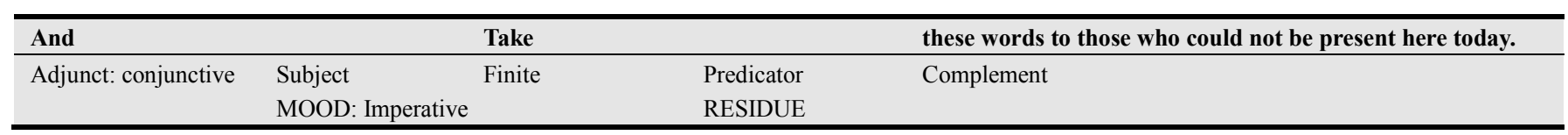

Clause 06. O People, just as you regard this month, this day, this city as sacred.

\begin{tabular}{|c|c|c|c|c|c|}
\hline O People & Just as & You & Regard & & This month, this day, this city as sacred \\
\hline \multirow[t]{2}{*}{ Adjunct: Vocative } & Adjunct: Conjunctive & Subject & Finite & Predicator & Complement \\
\hline & & \multicolumn{2}{|c|}{ MOOD: Declarative } & RESIDUE & \\
\hline
\end{tabular}

Clause 07. so regard the life and property of every Muslim as a sacred trust.

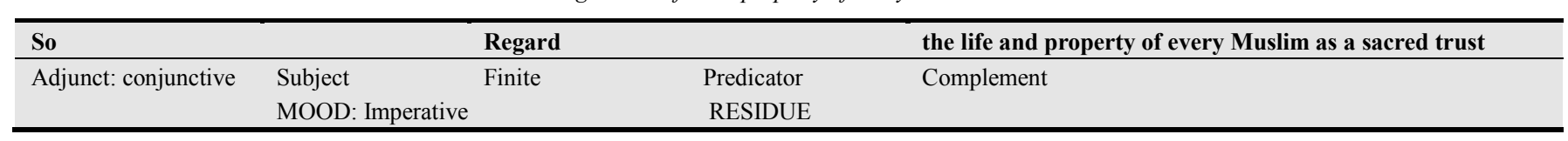

Clause 08. Return the goods entrusted to you to their rightful owners.

\begin{tabular}{llll}
\hline Return & & The goods entrusted to you & To their rightful owners \\
\hline Finite & Predicator & Complement & Adjunct: Circumstantial \\
MOOD: Imperative & RESIDUE & & \\
\hline
\end{tabular}

Clause 09. Hurt no one.

\begin{tabular}{lll}
\hline Hurt & No one \\
\hline Finite & Predicator & Complement \\
MOOD: Imperative & RESIDUE & \\
\hline
\end{tabular}

Clause 10. so that no one may hurt you.

\begin{tabular}{lllll}
\hline So that & No one & may & Hurt & You \\
\hline \multirow{2}{*}{ Adjunct: conjunctive } & Subject & Finite: Modal & Predicator & Complement \\
& MOOD: Declarative & RESIDUE & \\
\hline
\end{tabular}

Clause 11. Remember that you will indeed meet your Lord.

\begin{tabular}{llll}
\hline Remember & & That & you will indeed meet your Lord \\
\hline Finite & Predicator & Adjunct: conjunctive & Complement \\
MOOD: Imperative & RESIDUE & & RESIDUE \\
\hline
\end{tabular}

Clause 12. and that He will indeed reckon your deeds.

\begin{tabular}{|c|c|c|c|c|}
\hline and that & Will & Indeed & Reckon & Your deeds \\
\hline Adjunct: conjunctive & $\begin{array}{ll}\text { Subject } & \text { Finite: Modal }\end{array}$ & Adjunct: Mood & Predicator & Complement \\
\hline & \multicolumn{2}{|l|}{ MOOD: Declarative } & RESIDUE & \\
\hline
\end{tabular}

Clause 13. Allah has forbidden you to take usury (interest).

\begin{tabular}{lllll}
\hline ALLAH & has & Forbidden & You & To take usury (interest) \\
\hline Subject & Finite & Predicator & Complement & Complement \\
MOOD: Declarative & & RESIDUE & & \\
\hline
\end{tabular}


Clause 14. therefore all interest obligations shall henceforth be waived.

\begin{tabular}{lllll}
\hline Therefore & All interest obligation & shall & Henceforth & be waived \\
\hline Adjunct: conjunctive & Subject & Finite: Modal & Adjunct: Conjunctive & Predicator \\
& MOOD: Declarative & & & RESIDUE \\
\hline
\end{tabular}

Clause 15. Your capital, however, is yours to keep.

\begin{tabular}{llll}
\hline Your capital & However & Is & Yours to keep \\
\hline Subject & Adjunct: Mood & predicator & Complement \\
MOOD: Declarative & & RESIDUE & \\
\hline
\end{tabular}

Clause 16. You will neither inflict nor suffer any inequity.

\begin{tabular}{llll}
\hline You & Will neither, nor & Inflict, suffer & Any inequity \\
\hline Subject & Finite: Modal: Negative & Predicator & Complement \\
MOOD: Declarative & & RESIDUE & \\
\hline
\end{tabular}

Clause 17. I cancel the debts of interest payable to my uncle, Abbas ibn Abdul Muttalib.

\begin{tabular}{llll}
\hline I & Cancel & & The debts of interest Payable to my uncle, Abbas ibn Abdul Muttalib \\
\hline Subject & Finite & Predicator & Complement \\
MOOD: Declarative & & RESIDUE & \\
\hline
\end{tabular}

Clause 18. "O People, your wives have a certain right over you.

\begin{tabular}{llll}
\hline O people, & Your wives & Have & A certain right over you \\
\hline Adjunct: vocative & Subject & Predicator & Complement \\
& MOOD: Declarative & RESIDUE & \\
\hline
\end{tabular}

Clause 19. and you have a certain right over them.

\begin{tabular}{llll}
\hline And & You & Have & A certain right over them \\
\hline Adjunct: conjunctive & Subject & Predicator & Complement \\
& MOOD: Declarative & RESIDUE & \\
\hline
\end{tabular}

Clause 20. Treat them well.

\begin{tabular}{llll}
\hline Treat & & Them & Well \\
\hline Finite & Predicator & Complement & Adjunct: circumstantial \\
MOOD: Imperative & RESIDUE & & \\
\hline
\end{tabular}

Clause 21. and be kind to them.

\begin{tabular}{llll}
\hline And & Be & Kind & To them \\
\hline Adjunct: conjunctive & Predicator & complement & Adjunct: circumstantial \\
& RESIDUE & & \\
\hline
\end{tabular}

Clause 22. for they are your partners and committed helpers.

\begin{tabular}{llll}
\hline For & They & Are & Your partners and committed helpers \\
\hline Adjunct: conjunctive & Subject & Predicator & Complement \\
& MOOD: Declarative & RESIDUE & \\
\hline
\end{tabular}

Clause 23. "Beware of Shaytaan.

\begin{tabular}{lll}
\hline Beware & Of Shaytaan \\
\hline Finite & Predicator & Complement \\
MOOD: Imperative & RESIDUE & \\
\hline
\end{tabular}

Clause 24. he is desperate to direct you away from the worship of Allah.

\begin{tabular}{llll}
\hline He & Is & Desperate to direct you & From the worship of Allah \\
\hline Subject & Predicator & complement & Adjunct: circumstantial \\
MOOD: Declarative & RESIDUE & & \\
\hline
\end{tabular}


Clause 25. so beware of him in the matters of religion.

\begin{tabular}{lllll}
\hline So & Beware & & Of him & In the matters of religion \\
\hline Adjunct: conjunctive & Finite & Predicator & complement & Adjunct: circumstantial \\
& MOOD: Imperative & RESIDUE & & \\
\hline
\end{tabular}

Clause 26. O People, Listen carefully.

\begin{tabular}{llll}
\hline O people & Listen & Carefully \\
\hline Adjunct: vocative & Finite & Predicator & Complement \\
& MOOD: Imperative & RESIDUE & \\
\hline
\end{tabular}

Clause 27. all believers are brothers.

\begin{tabular}{lll}
\hline All believers & Are & Brothers \\
\hline Subject & Predicator & Complement \\
MOOD: Declarative & RESIDUE & \\
\hline
\end{tabular}

Clause 28. You are not allowed to take the things belonging to another Muslim.

\begin{tabular}{llll}
\hline You & Are not & Allowed to take & The things belonging to another Muslim \\
\hline Subject & Finite: Negative & Predicator: Modulated: complex & Complement \\
MOOD: Declarative & & RESIDUE & \\
\hline
\end{tabular}

Clause 29. unless he gives it to you willingly.

\begin{tabular}{|c|c|c|c|c|c|c|}
\hline Unless & he & Gives & & It & To you & Willingly \\
\hline \multirow[t]{2}{*}{ Adjunct: conjunctive } & Subject & Finite & Predicator & complement & Complement & Adjunct: Circumstantial \\
\hline & MOOD: Declarative & & RESIDUE & & & \\
\hline
\end{tabular}

Clause 30. "O People, none is higher than another.

\begin{tabular}{llll}
\hline O People & None & Is & Higher than another \\
\hline Adjunct: vocative & Subject & Predicator & Complement \\
& MOOD: Declarative & RESIDUE & \\
\hline
\end{tabular}

Clause 31. unless he is higher in the obedience to Allah.

\begin{tabular}{llll}
\hline Unless & He & Is & Higher in the obedience to ALLAH \\
\hline Adjunct: conjunctive & Subject & Predicator & Complement \\
& MOOD: Declarative & RESIDUE & \\
\hline
\end{tabular}

Clause 32. No Arab is superior to a non-Arab except in piety.

\begin{tabular}{lll}
\hline No Arab & Is & Superior to a non-Arab except in piety \\
\hline Subject & Predicator & Complement \\
MOOD: Declarative & RESIDUE & \\
\hline
\end{tabular}

Clause 33. "O People, reflect on my words.

\begin{tabular}{llll}
\hline O People & Reflect & & On my words \\
\hline Adjunct: vocative & Finite & Predicator & Complement \\
& MOOD: Imperative & RESIDUE & \\
\hline
\end{tabular}

Clause 34. I leave behind two things, the Holy Quran and my Example.

\begin{tabular}{llll}
\hline I & Leave & & Behind two things, the Holy Quran and my Example \\
\hline Subject & Finite & Predicator & Complement \\
MOOD: Declarative & & RESIDUE & \\
\hline
\end{tabular}

Clause 35. and if you follow these two.

\begin{tabular}{lllll}
\hline And if & You & Follow & & These two \\
\hline Adjunct: conjunctives & Subject & Finite & Predicator & Complement \\
& MOOD: Declarative & & RESIDUE & \\
\hline
\end{tabular}


Clause 36. you will not go astray

\begin{tabular}{llll}
\hline You & Will not & Go & Astray \\
\hline Subject & Finite: Negative & Predicator & Adjunct: Circumstantial \\
MOOD: Declarative & & RESIDUE & \\
\hline
\end{tabular}

Clause 37. Listen to me carefully.

\begin{tabular}{llll}
\hline Listen & & To me & Carefully \\
\hline Finite & Predicator & Complement & Adjunct: Circumstantial \\
MOOD: Imperative & RESIDUE & & \\
\hline
\end{tabular}

Clause 38. Worship Allah.

\begin{tabular}{lll}
\hline Worship & ALLAH \\
\hline Finite & Predicator & Complement \\
MOOD: Imperative & RESIDUE & \\
\hline
\end{tabular}

Clause 39. and offer Salaah.

\begin{tabular}{llll}
\hline And & Offer & & Salaah \\
\hline Adjunct: conjunctives & Finite & Predicator & Complement \\
& MOOD: Imperative & RESIDUE & \\
\hline
\end{tabular}

Clause 40. observe Saum (fasting) in the month of Ramadan.

\begin{tabular}{llll}
\hline Observe & & Saum (fasting) & In the month of Ramadan \\
\hline Finite & Predicator & Complement & Adjunct: Circumstantial \\
MOOD: Imperative & RESIDUE & & \\
\hline
\end{tabular}

Clause 41. and pay Zakaah.

\begin{tabular}{llll}
\hline And & Pay & Zakaah \\
\hline Adjunct: conjunctives & Finite & Predicator & Complement \\
& MOOD: Imperative & RESIDUE & \\
\hline
\end{tabular}

Clause 42. O People be mindful of those who work under you.

\begin{tabular}{llll}
\hline O people & Be & & Mindful of those who work under you \\
\hline Adjunct: Vocative & Finite & Predicator & Complement \\
& MOOD: Imperative & RESIDUE & \\
\hline
\end{tabular}

Clause 43. Feed and clothe them.

\begin{tabular}{lll}
\hline Feed and clothe & Them & Complement \\
\hline Finite & Predicator & \\
MOOD: Imperative & RESIDUE & \\
\hline
\end{tabular}

Clause 44. as you feed and clothe yourself.

\begin{tabular}{lllll}
\hline As & You & Feed and clothe & Yourself \\
\hline Adjunct: conjunctives & Subject & Finite & Predicator & Complement \\
& MOOD: Declarative & & RESIDUE & \\
\hline
\end{tabular}

Clause 45. O People, no prophet or messenger will come after me.

\begin{tabular}{lllll}
\hline O People & No prophet or messenger & will & Come & After me \\
\hline Adjunct: Vocative & Subject & Finite: Modal & Predicator & Adjunct: Circumstantial \\
& MOOD : Declarative & & RESIDUE & \\
\hline
\end{tabular}

Clause 46. and no new faith will emerge.

\begin{tabular}{llll}
\hline And & No new faith & Will & Emerge \\
\hline Adjunct: Conjunctive & Subject & Finite: Model & Predicator \\
& MOOD: Declarative & & RESIDUE \\
\hline
\end{tabular}


Clause 47. "All those who listen to me will pass on my words to others, and those to others again.

\begin{tabular}{lllll}
\hline All those who listen to me & Will & Pass on & My words & To others, and those to others again \\
\hline Subject & Finite: Modal & Predicator & Complement & Adjunct: circum \\
MOOD: Declarative & & RESIDUE & & \\
\hline
\end{tabular}

Clause 48. "Have I conveyed the Message of Allah to you, O! People?"

\begin{tabular}{llllll}
\hline Have & I & conveyed & The message of ALLAH & To you & O People \\
\hline Finite & Subject & Predicator & complement & Complement & Adjunct: Voc \\
MOOD: Interrogative & & RESIDUE & & & \\
\hline
\end{tabular}

Clause 49. The Sahaba answered in one voice, "Yes, you have.

\begin{tabular}{|c|c|c|c|c|}
\hline The Sahaba & answered & & In one voice & Yes, you have \\
\hline $\begin{array}{l}\text { Subject } \\
\text { MOOD: Declarative }\end{array}$ & Finite & $\begin{array}{l}\text { Predicator } \\
\text { RESIDUE }\end{array}$ & Adjunct: circumstantial & Complement \\
\hline
\end{tabular}

Clause 50. Allah is the Witness.

\begin{tabular}{lll}
\hline ALLAH & Is & The Witness \\
\hline Subject & Predicator & Complement \\
MOOD: Declarative & RESIDUE & \\
\hline
\end{tabular}

Clause 51. The Holy Prophet (Sallallahu Alaihi Wasallam) then said, "O! Allah, You are my Witness."

\begin{tabular}{lllll}
\hline The Holy Prophet (Sallallahu Alaihi Wasallam) & Then & Said & O ALLAH, You are my Witness \\
\hline Subject & Adjunct: Circumstantial & Finite & Predicator & Complement \\
MOOD: Declarative & RESIDUE & MOOD & RESIDUE & \\
\hline
\end{tabular}

Clause 52. As the Holy Prophet (Sallallahu Alaihi Wasallam) finished his sermon.

\begin{tabular}{lllll}
\hline As & The Prophet(Sallallahu Alaihi Wasallam) & Finished & & His sermon \\
\hline Adjunct: Conjunctive & Subject & Finite & Predicator & Complement \\
& MOOD: Declarative & & RESIDUE & \\
\hline
\end{tabular}

Clause 53. Allah Almighty revealed the following last verse of the Holy Quraan.

\begin{tabular}{|c|c|c|c|}
\hline ALLAH Almighty & Revealed & & The following last verse of the Holy Quraan \\
\hline $\begin{array}{l}\text { Subject } \\
\text { MOOD: Declarative }\end{array}$ & Finite & $\begin{array}{l}\text { Predicator } \\
\text { RESIDUE }\end{array}$ & Complement \\
\hline
\end{tabular}

Clause 54. Today, I have perfected your religion for you.

\begin{tabular}{|c|c|c|c|c|c|}
\hline Today & I & have & Perfected & Your religion & for you \\
\hline $\begin{array}{l}\text { Adjunct: Circumstantial } \\
\text { RESIDUE }\end{array}$ & $\begin{array}{l}\text { Subject } \\
\text { MOOD: Declarative }\end{array}$ & Finite & $\begin{array}{l}\text { Predicator } \\
\text { RESIDUE }\end{array}$ & Complement & Complement \\
\hline
\end{tabular}

Clause 55. completed my favor upon you.

\begin{tabular}{llll}
\hline Completed & & My favor & Upon you \\
\hline Finite & Predicator & Complement & Adjunct: Circumstantial \\
MOOD: Imperative & RESIDUE & & \\
\hline
\end{tabular}

Clause 56. and have chosen Islam as the way of your life."

\begin{tabular}{llll}
\hline And & Have & chosen & Islam As the way of your life \\
\hline Adjunct: Conjunctive & Finite & Predicator & Complement \\
& MOOD: Imperative & RESIDUE & \\
\hline
\end{tabular}

\subsection{Data Discussion}

Data analysis presents Mood of the clauses which further reflects their functional meanings. Three types of clausal Moods have been found during analysis; Declarative, Imperative and Interrogative. Each of the type indicates different sort of interpersonal relationship among the participants. Declarative Mood of the clause shows the expression conclusive, strong and factual whereas Imperative Mood expresses authority. It presents a deletion of the Subject (agent/ doer) and describes the status and/or power relations of the participants involved in the discourse. On the other hand, Interrogative Mood also reflects interpersonal relations of the participants with respect to their status and social roles (Kamalu and Tamunobelema, 2013). 
Declarative Mood has been found most frequently in the data analyzed. 32 /56 clauses are of declarative Mood which indicate that the communicated information is very strong and factual based. This Mood type strengthens the text's appeal to the readers/ listeners. Communicative functionality of language constructs social realities. Religious preaching bases on strong language demonstration. The Declarative Mood fulfills the said demand. Most of the Declarative clauses of the data offer strong religious realities that show interpersonal relations. The speaker has a high and influential status among the audience present there.

The second mostly found Mood type is Imperative. 22 out of 56 clauses have been analyzed. Imperative clauses present absence of the Subject and begin directly with the processes. This clause configuration expresses command or request. Context of situation and domain distinguish between both of the functions; command or request. In religious context it is explicit that the speaker entertains the authority to order. The Holy Prophet (PBUH) delivered His Address with full authority. This implicates power hierarchy among the speaker and the audience.

The least found Mood type is interrogative. Only one clause (clause: 48) explicates interrogative Mood. This clause reinforces the force of other declarative and imperative Mood clauses. It is not a $w h$-question clause rather a yes/ no question clause. It simply offers two options and no liberty is given on the part of the audience. This function states the power relations.

\subsection{Distinctive Characteristic in Data Discussion}

Another distinctive feature noticed here is the classification of Vocative Adjunct. The vocative phrase "O People" has been uttered frequently in the address. It validates the universality of the address. The addressees are not only the Muslims present there rather the general public of the world. This feature of language of the address confirms that the address is free of time and place constraints. It is valid for all the people of every generation and all ages.

\section{Conclusion}

Summing up the discussion, it is evident that the functional structural based Mood analysis of the text is very useful in order to understand interpersonal relationships of the participants. The order of the clause elements provides categorization of the Mood of the clauses. This classification further employs certain meaning according to the clause type.

The language analysis of religious texts according to SFL Mood analysis is a useful strategy and needs further investigation with reference to different contexts. Religious texts are least investigated genre of language. The current study is a valuable addition to the work done by previous researchers. It provides a good starting point to the learners as well by owing to its practical nature. The presentation of tabulated forms is also very helpful for the beginners. The address of the Holy Prophet (PBUH) offers an authentic linguistic material for the analysis and suggests objective evaluation in terms of linguistics.

\section{References}

[1] Ayoola. \& Olusanya, M. (2013). An interpersonal metafunction analysis of some selected political advertisements in some Nigerian newspapers. International Journal of Humanities and Social Science 3(8): 165.

[2] Banks, D. (2002). Systemic functional linguistics as a model for text analysis. Asp Varia, 35-36. Retrieved from asp.revues.org > Numéros > 35-36 > Articles on 2/3/14.

[3] Bayram, F. (2010). The last prophet: Prophet Muhammad. lastprophet.info TR DE RU Retrieved from www.lastprophet.info/the-last-prophet-prophet-muhammad on $6 / 3 / 14$

[4] Behnam, B. \& Kazemian, B. (2013). A comparative study of ideational grammatical metaphor in scientific and political texts. The Journal of Applied Linguistics and Discourse Analysis, 1(1), 40-70.

[5] Buttt, D., Fahey, R., Feez, S. (2003). Using Functional Grammar-- An Explorer's Guide. Sydney: National Centre for English Language Teaching and Research.

[6] Christie, F. \& Unsworth, L. (2000). Developing Socially Responsible Language Research, In Len, U. (ed.) Researching Language in Schools and Communities: Functional Linguistic Perspective. London and Washington: Cassell.1-12.

[7] Costetchi, E. (2013). A method to generate simplified Systemic Functional Parses from Dependency Parses. Retrieved from aclweb.org/anthology//W/W13/W13-3709.pdf on $4 / 3 / 14$

[8] Halliday, M.A.K. (1994). An Introduction to Functional Grammar (2nd Ed). London: Edward Arnold.

[9] Kamalu, I. \& Tamunobelema, I. (2013). Linguistic Expression of Religious Identity and Ideology in Selected Postcolonial Nigerian Literature. Canadian Social Science 9(4). 78-84

[10] Kazemian, B., Behnam, B. \& Ghafoori, N., (2013). Ideational grammatical metaphor in scientific texts: A Hallidayan perspective. International journal of Linguistics, 5(4), 146-168. http://dx.doi.org/10.5296/ijl.v5i4.4192

[11] Kazemian, B. \& Hashemi, S., (2014a). Nominalizations in scientific and political genres: a systemic functional linguistics perspective. International Journal of Humanities and Social Sciences, 3(2), 211-228. Retrieved from http://papers.ssrn.com/sol3/papers.cfm?abstract_id=2514388

[12] Kazemian, B. \& Hashemi, S., (2014b). Critical discourse analysis of Barack Obama's 2012 speeches: Views from systemic functional linguistics and rhetoric. Theory and Practice in Language Studies, 4(6), 1178-1187. doi:10.4304/tpls.4.6.1178-1187

[13] Kazemian, B., (2014). Hallidayan ideational grammatical metaphor in specialized texts. Germany: LAP LAMBERT Academic Publishing. Retrieved from http://www.amazon.com/Hallidayan-Ideational-GrammaticalMetaphor-Specialized/dp/3659517712

[14] Martinez, I, A. (2001). Impersonality in the research article as revealed by analysis of the transitivity structure. English for special purposes.20 (3). 227-247. 
[15] Moji, A, M. (2011). A systemic analysis of editorials in selected Nigerian newspapers. Bachelor Thesis. Retrieved from www.unilorin.edu.ng/studproj/arts/0715cd049.pdf on $26 / 2 / 14$

[16] O'Halloran, K, L. (2008). Systemic functional-multimodal discourse analysis (SF-MDA): constructing ideational meaning using language and visual imagery. Visual Communication.7; 443. DOI: 10.1177/1470357208096210

[17] Post, M. (2008). Disruptive Innovation: A Systemic Linguistic Analysis of Two Texts Detailing the Exhibition-Design and the Elastic Mind. Master's Thesis. Retrieved from www.birmingham.ac.uk/Documents/.../MPostFGessayDisrupti veInnovati... on $7 / 3 / 14$
[18] White, P. R. R. (2000). Functional Grammar. Birmingham: University of Birmingham.

[19] Ye, R. (2010). The Interpersonal Metafunction Analysis of Barack Obama's. English Language Teaching. 146. www.ccsenet.org/elt

[20] Young, L., \& Harrison, C. (2004). Systemic functional linguistics and critical discourse analysis. London: Continuum. 